\title{
KESESUAIAN PILIHAN KONSEP BISNIS, OPERASIONALISASI KEGIATAN DAN PENELITIAN DALAM PEMASARAN
}

\author{
Albari \\ Fakultas Ekonomi Universitas Islam Indonesia \\ e-mail: albari@uii.ac.id
}

\begin{abstract}
There are many differences of opinion between the experts from other scholars when they view the development of marketing discipline although they have different backgrounds competence. But that differences of opinion helped the development of the marketing discipline is faster. This article does not attempt to enliven the debate, but rather provides another discourse by pointing out the need for better harmonization between business concepts with the operationalization of the marketing aspects, including the option of the research approach, both in the context of the development of science as well as linkages with marketing applications.
\end{abstract}

Keywords: business concept, operational activities, marketing research

\begin{abstract}
Abstrak
Perkembangan disiplin ilmu pemasaran banyak dijumpai adanya perbedaan pendapat antara satu ahli dengan ahli yang lain, meskipun dengan latarbelakang kompetensi ilmu yang berbeda. Namun waktu juga mencatat bahwa perbedaan pendapat tersebut justru membantu perkembangan disiplin pemasaran lebih cepat dan kaya. Artikel ini tidak mencoba meramaikan perdebatan tersebut, tetapi justru memberikan wacana lain dengan menunjukkan perlunya adanya keselarasan antara konsep bisnis dengan operasionalisasi aspek-aspek pemasaran yang lain, termasuk untuk menetapkan pilihan pendekatan penelitian, baik dalam konteks pengembangan ilmu maupun keterkaitan dengan aplikasi pemasarannya.
\end{abstract}

Kata Kunci: konsep bisnis, operasionalisasi kegiatan, penelitian pemasaran

\section{PENDAHULUAN}

Mintzberg (2005) pernah melakukan evaluasi mengenai perkembangan suatu teori. Mintzberg memulai dengan suatu pertanyaan: what theory isn't: true. Pertanyaan tersebut muncul karena adanya pengalaman sebelumnya yang menunjukkan bahwa suatu teori yang muncul tetapi berbeda dengan teori yang sudah ada, bahkan sudah menjadi dogma, akan banyak mendapat tantangan. Sebagai contoh, Columbus yang mengajukan teori bahwa bumi itu bulat, yang pada saat itu berbeda dengan dogma bahwa bumi itu datar, membuatnya mendapat kritik keras dan dianggap sebagai suatu teori yang salah. Menurut Mintzberg, hal itu terjadi karena seseorang sering memilih teori sesuai dengan yang diinginkannya, bukan dengan mengkritisi kebenaran teori tersebut. Artinya seseorang dalam menggunaan suatu teori banyak didasar- kan pada keinginan pengguna teori atau teori yang sering digunakan dalam penelitian, dan bukan berdasarkan pada teori yang paling baik untuk memecahkan masalah yang dihadapi. Padahal dengan mengkritisi teori yang beragam pengguna akan lebih lengkap dalam berpikir dan menjelaskan suatu fenomena serta mencari jalan untuk menghasilkan sebuah teori alternatif.

Berkaitan dengan pengembangan suatu teori, Mintzberg (2005) juga mencatat bahwa tidak semua teori dipandang sebagai suatu yang obyektif, misalnya karena adanya perbedaan pendekatan atau metodologi. Mintzberg memberikan 2 contoh; pertama, berkaitan dengan birokrasi penelitian, yaitu ketika beberapa editor suatu jurnal menolak untuk menerbitkan artikel teori relativitas Albert Einstein karena dianggap hanya hasil pemikiran spekulatif. Kedua, berkaitan dengan pendapat Karl Popper 
yang lebih percaya pada fakta-fakta yang diperoleh dari proses diduksi dan menolak pendekatan induksi, karena induksi tidak didasarkan pada fakta. Padahal menurut Alfred Hirshman suatu model tidak pernah dikalahkan oleh fakta, tetapi hanya oleh model yang lain. Sementara itu, berkaitan dengan penelitian kualitatif dan kuantitatif, Mintzberg berpendapat bahwa tidak semua penelitian kualitatif menggunakan pendekatan induktif atau penelitian kuantitatif melalui pendekatan diduktif.

Evaluasi Mintzberg tersebut perlu dianggap penting dikemukakan untuk mengawali diskusi tenang pemasaran ini, karena dalam perkembangannya pemasaran banyak mengalami evolusi pengertian, pendekatan dan analisis dari waktu ke waktu. Evolusi itu tidak saja terjadi antara spesialis pemasaran dengan spesials pemasaran yang lain dengan berbagai dasar pemikiran yang mungkin berbeda, tetapi bisa juga evolusi dari seorang spesialis pemasaran sendiri, misalnya yang dilakukan oleh Kotler (1984; Kotler and Keller, 2009) atau yang diidentifikasikan Bartels (Shaw and Tamilia, 2001). Adanya evolusi tersebut, bahkan jika pun adanya perbedaan, adalah sesuatu yang wajar dan akan membantu pada perkembangan disiplin pemasaran (Brown, 2002) ke arah yang lebih cepat dan kaya (Bagozzi and Nataraajan, 2000), seperti yang dinyakkan Mintzberg di atas. Bahkan dukungan seorang evaluator terhadap pendapat pakar tertentu dapat berubah menjadi desakan untuk melakukan redesain konsep baru ketika pakar tersebut melakukan kritik diri dan pengakuan bahwa konsepnya cacat. Situasi ini dijelaskan oleh Brown (2002).

Brown (2002) menilai bahwa Konsep Pemasaran Generik yang diajukan oleh Philip Kotler sebagai suatu statemen definitif karakter disiplin pemasaran yang penting, karena memberikan gambaran histori pemasaran yang awalnya sebagai sebuah disiplin manajemen yang ditujukan untuk meningkatkan teknik penjualan, dan akhirnya, sebuah ilmu perilaku terapan yang berkaitan dengan pemahaman sistem pembeli dan penjual. Namun, ketika kemudian Kotler sendiri menyatakan bahwa konsepnya cacat, Brown mengajak pakar lain untuk menyusun kembali konsep pemasaran yang fundamental untuk mengembangkan disiplin pemasaran ke depan.
Contoh yang lain juga dikemukakan oleh Brown (1995), yang mereview polemik yang dipicu oleh Levitt melalui artikel marketing myopia bahwa Levitt tidak hanya memicu dan bertanggung jawab munculnya kontradiksi dan ambigiu pada konsep pemasaran, tetapi juga mengingatkan pada esensi pemasaran modern dan menimbulkan resonansi dan daya retoris yang luar biasa dalam agenda diskusi generasi baru akademisi dan praktisi pemasaran, yang sebelumnya cenderung mengalami kemandegan.

Secara aplikatif juga dicontohkan oleh Grant (1999) tentang adanya perbedaan cara pandang mengenai kegiatan periklanan menurut Levitt dan Galbraith. Galbraith memandang fungsi utama iklan adalah untuk menciptakan permintaan pasar untuk produk hasil teknologi yang tersedia, sehingga Galbraith menganggap iklan sebagai promosi penjualan. Sementara itu Levitt berpendapat bahwa iklan harus memberitahu orang-orang tentang apa yang mereka inginkan, sebagai cerminan dari keinginan yang sudah ada pada pelanggan, karena pemasaran tidak menjual produk tetapi sebuah mimpi kecantikan, kesehatan, keberhasilan, kekuasaan, atau solusi untuk masalah yang ada.

Seperti halnya pada disiplin ilmu yang lain, pemasaran juga mengalami pasang-surut perdebatan tentang kecenderungan paradigma, filosofi, keilmuan, penelitian, bahkan sampai pada aplikasi strategi dan operasional kegiatan pemasaran. Bagi pakar pemasaran tertentu identifikasi kecenderungan itu tidak sepenting daripada pengetahuan pemasaran yang seharusnya diaplikasikan manajemen sehari-hari untuk menghadapi masalah bisnis terkini. Bisa jadi perdebatan yang berlangsung dianggap menjadi kontra-produktif untuk perkembangan aplikasi pemasaran, karena sumberdaya yang ada bisa tersita untuk memikirkan perdebatan kecenderungan tersebut. Kelompok ini bisa dilihat dari karya ilmiah mereka dalam pemasaran, misalnya Kotler. Jika diurut edisi terbitan literatur Manajemen Pemasaran yang dihasilkannya selama ini menunjukkan bahwa Kotler (yang kemudian bersama-sama Keller) tidak banyak membahas perdebatan tentang kecenderungan-kecenderungan tersebut (misat nya Kotler and Keller, 2009). Bahkan Peter dan Olson (1983) menganggap perdebatan mengenai pemasaran sebagai ilmu atau bukan 
(seni?) sebagian besar menjadi tidak produktif. Artinya sarjana pemasaran telah membandingkan perkembangan teori dan pengujian dalam pemasaran dengan standar yang tidak pantas dan tidak ada hubungannya dengan kegiatan penelitian ilmiah dalam bidang apapun.

\section{KAJIAN PUSTAKA}

Pada bagian ini dibahas tentang keterkaitan antara pengertian-pengertian penting dalam teori pemasaran sampai dengan kemungkinan perlunya tekanan penelitian di bidang pemasaran.

\section{Evolusi Pengertian Pemasaran}

Faktor yang mendasari sebuah filosofi pemasaran adalah sudut pandang seseorang tentang suatu fenomena pemasaran tertentu. Suatu filosofi mungkin tepat dikemukakan orang tertentu, pada saat tertentu, dan ketika mencermati masalah atau fenomena pemasaran dari titik pandang tertentu (Marketing Staff, 1965). Sudut pandang tentang fenomena pemasaran tersebut akan berdampak pada penetapan definisi pemasaran. Misalnya Hunt (1991) memberikan definisi pemasaran sebagai proses dalam masyarakat dimana permintaan struktur untuk barang ekonomi dan jasa diantisipasi, diperbesar, dan tercapainya kepuasan melalui promosi, konsepsi, pertukaran, dan distribusi fisik barang dan jasa. Definisi pemasaran tersebut sama seperti yang digunakan oleh Marketing Staff (1965).

Namun demkian, definisi pemasaran yang telah ada juga bisa mengalami perkembangan. Sebagai contoh adalah definisi pemasaran yang dipublikasikan oleh American Marketing Association -AMA (Graham 1993). Pada tahun 1948 AMA mendefinisikan pemasaran sebagai kinerja bisnis yang diarahkan pada aktifitas dan kejadian arus barang dan jasa dari produsen ke konsumen atau penggguna. Tetapi pada tahun 1960 berubah menjadi sebagai kinerja kegiatan yang mengarahkan arus barang dan jasa dari produsen ke konsumen atau penggguna. Sementara pada tahun 1985 berubah lagi menjadi proses perencanaan dan pelaksanaan konsepsi, penetapan harga, promosi dan ide distribusi barang dan jasa untuk menciptakan pertukaran dan memuaskan individu dan tujuan organisasi.
Kotler (1984) pernah mengemukakan bahwa pemasaran adalah satu proses sosial dengan mana individu dan kelompok yang mendapatkan apa yang mereka butuhkan dan inginkan dengan menciptakan dan mempertukarkan produk dan nilai dengan individu dan kelompok lainnya. Pada tahap berikutnya, pengertian pemasaran berkembang menjadi fungsi organisasi dan serangkaian proses untuk menciptakan, mengkomunikasikan, dan menyampaikan nilai kepada pelanggan dan untuk mengelola hubungan pelanggan dalam rangka mendapatkan manfaat organisasi dan stakeholder-nya (Kotler and Kelller, 2009).

Di samping itu Bartels (Shaw and Tamilia, 2001) menceriterakan saat istilah pemasaran pertama kali digunakan sebagai kata benda yang menunjukkan arah pemikiran pemasaran, dan kemudian berkembang menjadi kata kerja yang menunjukkan ke arah praktek pemasaran. Bartels juga mengelompokkan pengembangan pemikiran pemasaran melalui periode waktu diskrit, dengan dimulai pada Periode Discovery 1900-1910, Periode Konseptualisasi 1910-1920, Periode Integrasi 1920-1930, Periode Pembangunan 1930-1940, Periode Penilaian kembali 1940-1950, Periode Reconceptualization 1950-1960, Periode Diferensiasi 1960-1970, dan Periode Sosialisasi dari 1970. Meskipun berguna untuk menghitung dan melakukan analisis kuantitatif, tetapi periode waktu kurang cocok untuk deskripsi dan investigasi kualitatif. Menurut Bartel, daripada menggunakan periode waktu untuk menentukan suatu peristiwa, peneliti akan lebih baik mencatat suatu kejadian penting selama periode waktu tertentu.

Bagi Bartel tersebut dimensi waktu menjadi penting dalam diskusi tentang situasi pemasaran, terutama pada saat membahas tentang product life cycle (PLC) dan loyalitas merek. Dimensi waktu dapat membawa pada konsep pemasaran hubungan yang bisa berlanjut/kontinuitas antara pembeli dan penjual. Misalnya pembahasan tentang perilaku pasar selain bisa dikaitkan dengan waktu, juga bisa mengarah pada adanya kendala uang, keahlian, teknologi, dan masyarakat yang akan menganggu kesempatan pasar. Di samping itu juga dikaitkan dengan kendala institusional, fungsional, manajerial, perilaku pembeli, kegiatan maupun lingkungan pemasaran makro. 
Lebih lanjut Bartels (Shaw and Tamilia, 2001) menyatakan sumber munculnya perspektif waktu tersebut adalah nilai (value) yang saling menguntungkan untuk melakukan transaksi dan hubungan. Nilai tersebut dapat ditingkatkan dengan pendekatan ekonomi, perilaku ilmiah, persepsi, dan informasi. Masyarakat sebagai aspek untuk melakukan advokasi pengendalian hubungan kegiatan pemasaran, dalam kontek atau lingkup nasional dapat bermanfaat pada: (1) meningkatnya efisiensi perilaku pasar dengan meminimisasi proses inheren dalam advokasi filosofis, (2) dapat menstandardisasi pengaturan proses pemasaran, dan (3) kebijakan pemasaran nasional akan meningkat lebih baik dalam mengurangi streriotip negatif pada pemasaran.

Di samping dimensi waktu secara umum teori pemasaran mempunyai lingkup bahasan (Hunt, 1991) bahwa: (1) pemasaran adalah studi perilaku pasar antara pemasar dan pembeli, (2) perilaku pasar diukur sebagai unit atau satuan analisis berupa transaksi pasar, (3) pemasaran berfokus pada dinamika alami pemasaran yang dapat terjadi transaksi ulang antara dua kelompok pasar atau lebih, (4) pemasaran mempunyai kendala yang berasal dari pembeli dan kelompok stakeholder yang lain, (5) pemasaran berorientasi untuk menciptakan dan mendistribusikan nilai ke arah win-win solution antara semua pihak yang terlibat dalam pemasaran, dan (6) teori umum pemasaran mampu meningkatkan komunitas ilmu pengetahuan, sintaksis, semantik, dan kriteria metateori pragmatis. Menutut Hunt teori umum pemasaran tersebut mengikuti aturan bahwa pengembangan bisa didasarkan pada sistem, manajerial, atau kemungkinan/prediksi yang akan terjadi di masa depan.

Teori pemasaran tersebut juga dapat didasarkan pada dikotomi antara perspektif interaktif-noninteraktif dan perspektif ekonominonekonomi (Hunt, 1991). Kedua dikotomi tersebut jika dihubungkan akan membentuk empat matrik aliran pemikiran pemasaran, yaitu: (1) hubungan antara perspektif ekonomi dengan noninteraktif cenderung mengelompok pada diskusi tentang komoditas, fungsional dan regional, (2) sudut pandang nonekonomi dengan noninteraktif menegelompok pada bahasan tenang perilaku pembeli, aktifis sosial, dan pemasaran makro, (3) kombinasi hubungan antara perspektif interaktif dan ekonomi lebih fokus pada diskusi tentang institusi, fungsionalis dan manajerial, dan (4) keterkaitan perspektif interaktif dengan nonekonomi lebih tertuju pada bahasan tentang dinamika organisasional, sistem dan pertukaran sosial.

Lebih lanjut Hunt (1999) menyatakan dengan mengkaitkan banyaknya kendala sumber daya yang berasal dari lingkungan pemasaran (misalnya uang, waktu, teknologi dan pesaing), maka aliran pemikiran pemasaran dapat cenderung mempunyai perspektif atau sudut pandang parsial. Misalnya aliran pemasaran dengan perspektif tentang komoditas akan berfokus pada bahasan produk, fungsional pada kegiatan, institusional pada pelaku atau aktor, perspektif regional fokus pada cakupan pasar, manajerial fokus pada sisi penjual, perilaku beli kepada konsumen, atau aktivis/makro pemasaran mengarah pada fokus kepentingan publik.

Pada saat ini pemasaran tidak lagi dipersepsikan disiplin ilmu yang berdiri sendiri, tetapi dalam perkembangannya bisa berkaitan dengan disiplin ilmu ekonomi, psikologi, sosiologi, administrasi publik, pekerjaan sosial, ilmu politik, dan atau komunikasi massa. Itu sebabnya menjadikan pemasaran tidak hanya berfokus pada kegiatan menjual produk, namun juga kegiatan untuk, misalnya kebutuhan dan keinginan tersembunyi konsumen (pendekatan psikologi), mengkomunikasikan sesuatu yang dipunyai perusahaan (produk, merek) kepada pasar sasarannya (pendekatan komunikasi), dan tanggung jawab sosial perusahaan kepada pembeli, pemasok dan stakeholder yang lain (pendekatan sosiologi).

Dengan perkembangan seperti tersebut, pemasaran tidak lagi dipandang secara negatif dengan stereotip hanya bertumpu kepada eksploitasi pada sisi konsumen, sehingga akti fitas pemasaran menjadi lebih etis, berfungsi sosial, atau sebaliknya tidk memandang konsumen sebagai korban pemasar yang tidak bermoral atau tidak mempunyai tanggungjawab sosial dalam memenuhi kebutuhan dan keinginan konsumen. Pemasaran modern sudah mengindahkan pemasaran dengan perilaku yang bertanggungjawab sosial.

Secara aplikatif, pemasaran telah melewati tahapan ikatan bisnis tradisional yang dominan bertumpu pada manufaktur barang. Pada saat ini pemasaran telah memasuki pada tingkatan aplikasi di bidang perawatan 
kesehatan, pelayanan sosial, telekomunikasi dan politik. Maka kemudian dikenal bahasan lingkup pemasaran menjadi fokus pada bahasan, misalnya pemasaran jasa, pemasaran publik, emarketing, dan pemasaran politik (Gronroos, 1994). Aktifitas pemasaran juga tidak lagi sekedar berkaitan dengan pertukaran, tetapi memaksimalkan pertukaran hubungan antara dua pihak atau lebih (perusahaan dengan stakeholder).

Secara umum beberapa pengertian pemasaran mempunyai sifat atau inti kegiatan pemasaran, yang sesuai dengan indikasiindikasi yang telah dilakukan oleh Marketing Staff (1965) dan Bartels (1988), yaitu pemasaran dapat bersifat, misalnya sebagai kegiatan usaha; sebagai kelompok usaha yang terkait suatu kegiatan tertentu; sebagai fenomena perdagangan; sebagai kerangka pikiran bisnis; sebagai fungsi koordinatif, integratif dalam pembuatan kebijakan bisnis; sebagai proses ekonomi; sebagai struktur lembaga, seperti proses pertukaran atau mentransfer kepemilikan produk; sebagai proses konsentrasi, pemerataan, dan dispersi kegiatan ekonomi; sebagai penciptaan waktu, tempat, dan utilitas kepemilikan; sebagai kegiatan yang menginginkan kepuasan; atau sebagai proses penyesuaian permintaan dan pasokan.

\section{Konsep Bisnis dan Pemasaran}

Sifat pemasaran tersebut pada dasarnya dipandang sebagai konsep inti pemasaran, yang berfungsi membentuk pengertian dasar untuk memahami suatu masalah pemasaran. Konsep inti pemasaran berguna untuk memahami konteks pemasaran secara komprehensif, sejak dari kegiatan menganalisis, merencanakan, implementasi dan pengendalian program dan kegiatan pemasaran suatu perusahaan. Berkaitan dengan tujuan tersebut, Hunt (1991) menggolongkan konsep inti pemasaran dalam 3 dikotomi, yaitu (1) sektor atau organisasi profit-nonprofit, (2) lingkungan mikro-makro, dan (3) pendekatan/perspektif positif-normatif.

Tiga dikotomi dari Hunt (1991) tersebut dirinci lebih lanjut menjadi delapan matriks model pemasaran yang berkaitan dengan masalah, teori, model normatif, dan penelitian di bidang pemasaran. Sebagai contoh, (1) matriks model pemasaran profit-mikropositif mempunyai fokus tentang perilaku pem- beli dari konsumen individu, (2) model profitmikro-normatif fokus pada pengaruh bauran pemasaran, (3) model profit-makro-positif pada pola konsumsi agregat, (4) model profit-makronormatif lebih memperhatikan peran pemasaran untuk dapat kegiatan lebih efisien, (5) model nonprofit-mikro-positif pada pembelian konsumen pada barang-barang publik, (6) model nonprofit-mikro-normatif fokus pada pengaruh pemasaran sosial, (7) model nonprofit-makropositif lebih memperhatikan kerangka kerja institusi untuk barang-barang publik, dan (8) model nonprofit-makro-normatif pada peran kelompok masyarakat tentang politik menjual.

Konsep inti pemasaran seperti yang dikemukakan Hunt (1991) tersebut yang mendasari perkembangan pemasaran modern yang ditandai dengan munculnya berbagai hal yang berkaitan dengan disiplin pemasaran, seperti konsep bisnis atau pemasaran, filosofi atau paradigma, fungsi, teori, cara berpikir, dan metode penelitian pemasaran. Seperti halnya pada disiplin ilmu yang lain, seringkali perkembangan tidak hanya saling mendukung dan kemudian mengembangkan pendapat 'pakar' tentang pemasaran yang sudah ada, tetapi menjadi perdebatan atau polemik pendapat yang didasarkan argumentasi kuat masing-masing.

Dalam perkembangannya banyak dijumpai definisi konsep bisnis yang bertolak dari aksioma pada pertukaran nilai antara produsen dan konsumen. Misalnya Kotler and Keller (2009), yang mengelompokkan konsep alternatif yang mendasari langkah-langkah organisasi dalam merancang dan melaksanakan strategi pemasaran mereka, yaitu konsep produksi, produk, penjualan, pemasaran, dan pemasaran berwawasan sosial. Menurut Kotler and Keller, Konsep produksi bertolak dari pendapat bahwa konsumen akan menyukai produk dengan harga yang terjangkau, sehingga aktivitas perusahaan diarahkan pada peningkatan efiesiensi dalam berproduksi dan distribusi. Konsep produk cenderung pada pendapat bahwa konsumen lebih suka pada produk yang menawarkan kualitas, kinerja, dan fitur inovatif yang terbaik, sehingga perusahaan perlu fokus untuk melakukan perbaikan produk yang berkelanjutan.

Hal yang berbeda pada konsep penjualan, yang menyatakan bahwa konsumen hanya membeli produk perusahaan jika produk 
tersebut dijual dalam skala penjualan dan usaha promosi yang besar, sehingga perusahaan perlu kreatif dengan melacak prospek dan menjual produk berdasarkan manfaat produk. Sedangkan konsep pemasaran berpendapat bahwa tujuan organisasi tergantung pada pengetahuan akan kebutuhan dan keinginan target pasar dan memberi kepuasan yang diinginkan dengan lebih baik dari pada pesaing, sehingga perusahaan perlu berfokus pada nilai pelanggan yang menuju penjualan dan keuntungan. Sementara itu, konsep pemasaran berwawasan sosial menyatakan bahwa organisasi selain perlu menerapkan konsep pemasaran, perlu juga memberikan kesejahteraan konsumen dan masyarakat dalam jangka panjang.

Sementara itu Kotler dan Keller (2009) menetapkan konsep pemasaran berwawasan sosial sebagai konsep pemasaran yang holistik. Konsep pemasaran ini mencakup 4 aspek penting dalam pemasaran, yaitu: (1) pemasaran hubungan, yang menitik beratkan kegiatan dan program pemasaran tidak hanya hubungan yang harmonis antara perusahaan dengan pelanggan, tetapi juga antara perusahaan dengan stakeholder yang lain, (2) pemasaran terintegrasi, mencakup semua kegiatan dan program marketing-mix (4P atau 7P), (3) pemasaran internal, berkaitan dengan dibutuhkannya tingkatan manajemen dan depertemen-departemen (keuangan, logistik, penjualan dan lain lain) yang dapat membantu terlaksananya kelancaran kegiatan dan program pemasaran, serta (4) pemasaran kinerja, yang berkaitan dengan capaian kegiatan dan program pemasaran dalam lingkup akuntabilitas keuangan dan tanggung jawab sosial pemasaran, seperti keuntungan penjualan, tingkat pengembalian investasi, ekuitas merek dan pelanggan, etika, legalitas, lingkungan, dan komunitas pemasaran.

Kelima konsep bisnis tersebut menjadi pedoman praktisi pemasaran dalam kurun waktu yang cukup lama. Namun bagi Alsem and Kostelijk (2008) lima konsep tersebut belum cukup. Pada kondisi terjadinya persaingan industri yang ketat seperti sekarang ini, fokus pada sisi permintaan yang lebih mementingkan pelanggan perlu diimbangi dari sisi penawaran perusahaan, yaitu dengan menambah identitas merek sebagai wakil perusahaan berdasarkan pada kompetensi dan kemampuan sumber daya yang dimiliki perusahaan tersebut (Alsem and Kostelijk, 2008).

Menurut Alsem and Kostelijk, tambahan identitas merek sebagai cerminan keseimbangan perusahaan untuk memperhatikan pelanggan (lingkungan eksternal) dan kemampuan diri perusahaan (lingkungan internal). Jika perusahaan hanya berfokus pada pelanggan, maka pelanggan pada suatu saat dapat meminta produk yang tidak cocok dengan bisnis inti perusahaan. Jika hal ini terjadi, maka perusahaan akan segera mencapai tahapan yang sangat melelahkan. Oleh karena itu, identitas merek yang digunakan sebagai penyeimbang kepentingan pelanggan, harus (Alsem and Kostelijk, 2008): (1) berbasis pada sumber daya yang dimiliki oleh perusahaan, (2) perusahaan harus dapat mempengaruhi persepsi dan kebutuhan pelanggan dengan cara mengajar dan membuat pelanggan sadar akan kebutuhannya yang tidak terpenuhi, (3) melakukan hubungan antara identitas merek dan pelanggan secara konseptual bahwa pelanggan akan bereaksi lebih baik terhadap instrumen pemasaran merek yang mereka ketahui dari pada instrumen pemasaran merek yang tidak mereka ketahui, dan (4) perusahaan harus selalu menjaga kepercayaan merek, karena kepercayaan merupakan faktor kunci dalam komitmen hubungan dengan pelanggan.

Masing-masing konsep bisnis tersebut pada dasarnya dapat diaplikasikan oleh suatu perusahaan pada suatu waktu tertentu, bahkan pada masa sekarang, dan bukan sekedar berdasarkan perkembangan waktu yang berlanjut dari masa lalu ke masa mendatang. Namun pilihan suatu konsep yang tepat dilaksanakan suatu perusahaan tergantung pada kondisi internal dan eksternalnya, seperti kondisi persaingan dan regulasi yang ada. Suatu perusahaan bisa saja menjalankan konsep produksi jika lingkungan target pasar pada tingkatan menengah-bawah, terjadi persaingan produk dan merek yang sangat ketat serta tidak adanya aturan pembatasan harga terendah. Sebaliknya jika lingkungan eksternal menuntut partisipasi perusahaan untuk memperhatikan kesehatan dan lingkungan masyarakat dalam bisnisnya, maka konsep pemasaran berwawasan sosial perlu menjadi prioritas utama sebagai dasar kebijakan aktivitas perusahaan.

Jika dicermati bahasan yang berkaitan dengan pengertian dan konsep pemasaran 
tersebut, maka kegiatan perusahaan atau pemasar berfokus pada 3 hal utama, yaitu: (1) pemasar akan lebih berorientasi kepada konsumen atau pelanggan, (2) pemasar akan mengkonsentrasikan usaha pada keuntungan dari pada volume penjualan, dan (3) pemasar perlu bekerja sama lebih banyak dengan departemen fungsional perusahaan lainnya dalam rangka mencapai tujuan perusahaan secara menyeluruh (Laczniak, Lusch, and Udell, 1977).

Di samping itu terdapat beberapa gagasan mendasar tentang pemasaran, yaitu sebagai berikut (Marketing Staff, 1965): (1) pemasaran adalah konsep yang mempengaruhi formasi dan aspek adaptif dari budaya, (2) adanya kontribusi yang signifikan dari pemasaran dalam bidang-bidang seperti ekonomi, psikologi, sosiologi, antropologi, budaya ekologi, demografi, ilmu politik, dan sejarah; pada saat yang sama, pemasaran telah memiliki dampak signifikan terhadap isi dan metode disiplin ilmu serumpun, (3) dengan terus meningkatnya populasi, kapasitas produksi dan standar hidup, pemasaran akan menjadi semakin signifikan, dengan mengembangkan sarana yang lebih baik dan memperbesar pelayanan pasar, (4) pemasaran merupakan bagian integral dari keseluruhan proses produktif, dalam arti bahwa hal itu menambah nilai untuk barang dan jasa melalui penciptaan waktu, tempat, kepemilikan, dan informasi utilitas, dan (5) adanya pandangan yang luas dari pemasaran sosial tidak menghalangi proses spesialisasi fungsional dan mengurangi pentingnya kompetensi manajerial di divisi pemasaran suatu perusahaan bisnis.

\section{Paradigma Pemasaran}

Konsep bisnis yang berlaku umum pada suatu waktu tertentu membawa dampak pada perkembangan paradigma atau orientasi bisnis dan manajerial (Morgan, 1996). Ketika konsep produksi, produk dan penjualan menjadi dasar perencanaan srategis perusahaan paradigma bisnis yang berkembang adalah pentingnya terjadinya pertukaran antara perusahaan (produsen) dan konsumen. Paradigma tersebut implisit menunjukkan kedudukan perusahaan dalam posisi yang lebih dominan dibandingkan dengan konsumen, karena sifat pertukaran adalah kegiatan untuk mendapatkan obyek yang diinginkan dari seseorang dengan menawarkan sesuatu sebagai imbalannya (Kotler and Keller, 2009). Dalam konteks bisnis berarti perusahaan berusaha mendapatkan tanggapan positif (terjadinya pertukaran) terhadap sejumlah penawarannya, terutama berupa pembelian atau konsumsi oleh konsumen.

McInes (Sheth, Gardner, and Garret, 1988) menjelaskan bahwa pasar sebagai hasil hubungan manusia ketika pemasar dan pengguna barang dan jasa ekonomi bertemu untuk memuaskan kebutuhan dan keinginannya melalui pertukaran. Hal itu berarti bahwa perilaku pasar sebagai domain pemasaran. Potensi terjadinya pertukaran bisa berbeda karena cakupan geografi, pengelompokan institusi, suatu proses, atau klasifikasi aktifitas. Selain itu juga bisa didasarkan oleh banyaknya pembeli dan penjual yang melakukan transaksi.

Menurut Sheth, Gardner, and Garret (1988) potensi pertukaran tersebut bisa terjadi pada salah satu dari 4 kemungkinan, yaitu: (1) pada kondisi industri yang terintegtrasi secara vertikal, banyaknya pembeli dan penjual terbatas pada satu atau beberapa orang, maka akan terjadi orientasi koperatif dan koordinatif, (2) pada situasi industri defensif dengan satu pembeli dan banyak pembeli, maka orientasinya adalah dengan aliansi strategis dan politik, (3) untuk kaadaan industri yang teregulasi serta dengan kelompok pembeli yang banyak dan satu penjual digunakan orientasi persaingan alokasi dan dependen, dan (4) pada kondisi pasar persaingan industri dengan banyak pembeli dan juga banyak penjual, maka orientasi pemasarannya adalah dengan persaingan dan seleksi melalui promosi dan pembedaan yang kuat.

Jika kemudian hasil usaha pertukaran tersebut dinilai sebagai kinerja unit analisis, maka selain kemungkinan bisa terjadi kegiatan transaksi, tetapi bisa juga terjadi interaksi pasar tanpa mekanisme transaksi. Hal ini karena pertukaran diorientasikan untuk mentaati peraturan, pengiriman barang dan jasa karena pemberian hadiah dan pemberian toleransi pertukaran tertentu, penambahan nilai pelayanan dari pertukaran utama, peralatan, perbaikan dan pemeliharaan sebagai konsekuensi penciptaan perilaku pasar yang primer.

Namun seiring dengan semakin ketatnya persaingan diperlukan perkembangan 
baru menuju penerapan konsep bisnis yang lain Perubahan konsep tersebut membawa dampak pada perubahan paradigma pemasaran dari berusaha terjadinya pertukaran menjadi usaha untuk memuaskan konsumen yang lebih baik dibandingkan dengan pesaing. Tujuan akhir aktivitas bisnis juga berubah, dari tujuan untuk memperoleh keuntungan melalui volume penjualan menjadi mendapat laba melalui kepuasan konsumen. Dari sisi obyek pasar sasaran juga terdapat perubahan tujuan dari usaha memperoleh pembeli atau konsumen menjadi tujuan agar seseorang bersedia membeli ulang, bahkan dapat terbentuk kelompok pelanggan yang loyal pada produk dan perusahaan.

Konsep pemasaran dengan paradigma perusahaan untuk memuaskan pelanggan tersebut bertahan cukup lama sejak dipublikasikan sekitar 1960-an. Namun bagi Bagozzi and Nataraajan (2000) paradigma kepuasan masih dianggap terlalu sempit; mereka mengusulkan kriteria kebahagiaan sebagai konstruksi pengalaman pribadi dan sosial, yang melampaui sisi emosional dan keprihatinan moral. Menurut Bagozzi and Nataraajan (2000) tersebut perluasan paradigma diperlukan karena kebahagiaan sebagai cerminan dari lima indra yang berbeda: (1) merupakan respon terhadap keseimbangan pertemuan kepentingan adaptional produsen dan konsumen, (2) sebagai fasilitator dan inisiator pemikiran untuk tindakan berikutnya, (3) sebagai produk penyerapan dalam aktivitas kreatif atau proyek kehidupan, (4) sebagai aktualitas kualitas hidup secara keseluruhan, dan (5) merupakan manivestasi dari cinta dan spiritualitas agama.

Selain perubahan paradigma perusahaan dari memuaskan pelanggan menjadi pencapaian kebahagiaan seperti yang diusulkan Bagozzi and Nataraajan (2000) tersebut, pada waktu sebelumnya sempat juga muncul usulan perubahan paradigma perusahaan yang lain, yaitu untuk mencapai hubungan pemasaran (misalnya Gronroos, 1994). Paradigma hubungan, menurut Gronroos (1994) berupa hubungan jangka panjang dari kedua belah pihak dan dari waktu ke waktu saling mempelajari cara terbaik untuk berinteraksi dan mengurangi biaya hubungan pada pelanggan dan perusahaan. Sebuah hubungan yang memuaskan memungkinkan pelanggan untuk menghindari biaya transaksi penggantian pemasok (perusahaan) yang signifikan, sedangkan bagi perusahaan untuk menghindari pengeluaran biaya kualitas yang tidakperlu.

Selanjutnya Gronroos (1994) menyatakan dalam lingkup aplikasi hubungan pemasaran kadang-kadang ditunjukkan oleh citra perusahaan atau merek yang dapat membuat pelanggan melekat pada penjual, misalnya ketika pesaing memperkenalkan produk serupa iklan dan gambar yang memuat nama perusahaan dan merek dapat membantu dalam menjaga pelanggan, paling tidak dalam jangka pendek (darurat).

Paradigma hubungan pemasaran ini juga dinyatakan oleh Hunt (1991; 1994), yang berpendapat bahwa praktek pemasaran telah semakin berubah ke arah aliansi, kemitraan dan bentuk lain dari hubungan pemasaran, yang keberhasilannya membutuhkan kerjasama yang efektif antar pihak yang terlibat dalam kegiatan pemasaran, seperti pemasok komponen, pemasok penelitian, biro iklan, karyawan, lem baga keuangan, pemerintah, dan distributor; karena itu dibutuhkan pengembangan keunggulan bersaing perusahaan yang berkelanjutan yang pencapaiannya dapat terbantu dengan hubungan pemasaran dalam jangka panjang ini.

Keseimbangan kepentingan berdasarkan pada hubungan pemasaran jangka panjang ini yang mengilhami Alsem and Kostelijk (2008) mengajukan gagasan keseimbangan permintaan (pelanggan) dengan penawaran (perusahaan) melalui identitas merek dan kebutuhan pelanggan. Konsep bisnis yang menekankan pada keseimbangan identitas merek dan kepentingan pelanggan ini telah dibahas di bagian Konsep Pemasaran.

Di samping itu terdapat juga paradigma pemasaran yang baru dan berbeda yang dikemukakan oleh Stauss (2005). Stauss menyatakan perlunya penghapusan perbedaan perlakuan antara barang dan jasa, karena pada dasarnya semua barang dapat dinyatakan sebagai kegiatan pelayanan. Sebagai konsekuensi dari pendapat tersebut adalah tidak adanya lagi perbedaan antara lingkup pemasaran dalam pemasaran umum dengan jasa, sehingga bahasan tentang manajemen jasa dan manajemen kualitas jasa tidak lagi diperlukan, karena menurut logika baru ini, manajemen apapun, dalam segala hal adalah manajemen layanan. Paradigma manajemen 
layanan ini lebih cenderung sebagai bentuk pendekatan bisnis berdasarkan pada konsep pemasaran dan pemasaran berwawasan sosial.

Lebih jauh Stauss (2005) berargumen bahwa barang tidak memiliki nilai, karena nilai diciptakan dan dirasakan oleh pelanggan melalui kontak. Padahal pelanggan berinteraksi dengan perusahaan dalam menggunakan produk, sehingga dianggap ikut berpartisipasi dalam menciptakan nilai. Di samping itu transaksi barang biasanya menyiratkan hubungan sosial dan hukum dalam bentuk kontrak, jaminan atau janji suatu merek di masa depan. Untuk beberapa transaksi produk bisa dijumpai disertai dengan layanan. Namun untuk transaksi produk yang lain layanan tidak diperlukan, sehingga paradigma yang dikemukakan Stauss (2005) tersebut perlu dikuatkan dengan kajian empiris yang lebilmendalam.

\section{Ruang Lingkup Manajemen Pemasaran}

Konsekuensi logis dari perkembangan pengertian dan konsep pemasaran tersebut adalah adanya perubahan tugas-tugas bagian pemasaran. Pada saat ini, manajemen pemasaran sudah sebagai seni dan ilmu untuk menemukan, menarik, mempetahankan, dan menumbuhkan pelanggan sasaran dengan menciptakan, memberikan, dan mengkomunikasikan keunggulan nilai bagi pelanggan (Kotler dan Keller, 2009). Dengan demikian manajemen pemasaran tidak hanya bekerja berdasarkan kepada proses antisipasi kebutuhan pelanggan yang bersifat kontinyu, tetapi harus disertai dengan kebijakan yang sifatnya situasional dan kondisional pada lingkungan pemasaran yang ada.

Redefinisi dari Kotler dan Killer (2009) tersebut tidak lagi sekedar diarahkan pada upaya kegiatan pertukaran antara perusahaan dengan pelanggannya. Manajemen pemasaran tidak lagi hanya dikaitkan sebagai kegiatan pertukaran dari partisipasi antara perusahaan dengan pelanggannya, meskipun dalam proses pertukaran tersebut mengandung unsur kekuatan, bujukan, dan komitmen normative dan etis (Bagozzi, 1975). Manajemen pemasaran juga tidak hanya sekedar untuk mempengaruhi tingkat, jangkauan waktu, dan komposisi permintaan dengan suatu cara tertentu sehingga membantu organisasi untuk mencapai sasarannya, atau tidak hanya melakukan manajemen permintaan (Kotler, 1984).
Demikian pula manajemen pemasaran tidak lagi hanya dikaitkan untuk memuaskan keinginan dan kebutuhan yang dilakukan hanya melalui pemahaman tentang keterkaitan biaya, karena investasi yang berkaitan dengan biaya tersebut tidak dipandang sebagai sesuatu yang penting untuk mendapatkan kepuasan pelanggan, seperti halnya bisnis yang beorientasi kepada pada efisiensi biaya yang dikedepankan dalam pandangan manajemen produksi atau penjualan (Houston, 1986). Pada sisi yang lain Ames (1970) telah menunjukkan keluhan dari beberapa eksekutif perusahaan tentang semakin besarnya biaya yang harus dikeluarkan untuk menggaji staf pemasaran agar dapat diperoleh ide-ide iklan dan promosi atau yang digunakan untuk memuat iklan tersebut di media, sementara penjualan tidak menunjukkan peningkatan yang berarti atau bahkan para eksekutif tersebut tidak yakin bahwa iklan yang ada dibaca oleh pelanggannya. Keluhan itu karena perusahaan terjebak pada pentingnya aktualisasi laporan tahunan,

Levitt (1960) bahkan menilai bahwa berhentinya pertumbuhan perusahaan bukan karena melambatnya, berhentinya, atau jenuhnya pasar perusahaan, tetapi kegagalan manajemen pemasaran seringkali banyak disebabkan karena perusahaan salah dalam menilai kebutuhan dan keinginan pelanggan tentang produk. Perusahaan lebih memperhatikan produk yang mereka tawarkan daripada manfaat, pengalaman atau bahkan solusi yang dihasilkan dari mengkonsumsi produk-produk tersebut. Hal tersebut karena perusahaan hanya berfokus pada prediksi keinginan pelanggan yang ada tanpa memperhatikan kebutuhan dasar pelanggan. Padahal produk (dan jasa) hanya sebagai sarana untuk mengatasi masalah pelanggan. Jadi, ketika pelanggan membeli pasta gigi, perusahaan merasa pelanggan hanya agar giginya nampak putih-bersih atau kuat, namun faktanya bisa lebh dari itu. Pelanggan mungkin membutuhkan agar tidak merasa terganggu aktivitas dan pekerjaan sehari-hari karena terganggu oleh kesehatan giginya, atau mempunyai kepercayaan diri dalam tata pergaulan dengan lingkungan kerjanya.

Lebih jauh Levitt (1960) menunjukkan bahwa kegagalan manajemen tersebut karena 4 hal yang berpusat pada definisi bisnisnya, yaitu: (1) adanya kepercayaan yang berlebihan bahwa pertumbuhan perusahaan akan tercapai 
kerena semakin luasnya dan makmurnya penduduk, (2) adanya keyakinan bahwa tidak ada produk substitusi industri utama, (3) tingginya keyakinan bahwa akan selalu diperoleh efisiensi biaya dan keuntungan yang tinggi pada saat dilakukan produksi massal, dan (4) adanya keasyikan dengan produk yang cocok yang bisa dikendalikan dengan hati-hati berdasarkan percobaan ilmiah, perbaikan, dan pengurangan biaya produksi. Keempat hal tersebut karena adanya kesalahan manajemen yang berasumsi bahwa persaingan, selera, perkembangan teknologi, dan sumber daya dapat dikendalikan oleh perusahaan.

\section{Fungsi-Fungsi Pemasaran}

Dengan semakin ketatnya persaingan yang ada, maka perusahaan perlu merevitalisasi fungsi fungsi pemasaran yang semakin lengkap agar mampu memenangkan persaingan. Hal itu berarti perusahaan perlu memuaskan pelanggan lebih baik dibandingkan pesaing, tetapi juga memanfaatkan kelebihan tersebut untuk menjalin hubungan jangka panjang dengan para pelanggannya.

Ames (1970) berpendapat perlunya peninjauan ulang terhadap konsep pemasaran yang mencakup pada 4 fungsi pemasaran, yaitu (1) berorientasi pada peningkatan kinerja (laba), karena pencapaian kinerja yang menghasilkan laba dapat menjamin kontinuitas aktivitas perusahaan dalam jangka panjang, (2) mengidentifikasikan kebutuhan pelanggan, karena banyak perusahaan berhasil menciptakan produk yang lebih efisien tetapi gagal dalam penjualan karena tidak sesuai dengan kebutuhan dasar kebanyakan para pelanggannya, (3) memilih kelompok pelanggan untuk penekanan agar perusahaan dapat lebih efektif dalam membuat dan menjalankan strategi yang sesuai dengan masing kelompok pelanggan, yang pada akhirnya akan diperolehnya efisiensi kegiatan pemasaran, dan (4) merancang paket produk dan jasa, karena seringkali pelanggan tidak hanya membutuhkan suatu produk atau jasa saja untuk memenuhi kebutuhan dan keinginannya, tetapi serangkaian produk dan jasa sebelum, pada saat, dan pasca pembelian atau konsumsi suatu produk/jasa. Untuk itu, bagian pemasaran harus mempunyai komitmen untuk melakukan aktifitas-aktifitas tersebut, bekerjasama secara fungsional dengan depertemen-departemen yang lain, siap untuk melakukan investasi dalam jangka panjang, dan jujur untuk menghadapi kekurangan yang terjadi akibat pengambilan keputusan manajemen sebelumnya.

Mengambil contoh ruang lingkup fungsi pemasaran seperti yang dikemukakan Ames (1970) tersebut, maka secara umum fungsi pemasaran dapat meliputi kegiatan seperti yang ditunjukkan oleh Marketing Staff (1965) dan Bartels (1988), seperti yang telah disampaikan pada bagian evolusi pengertian pemasaran sebelumnya. Bahkan kerangka bauran pemasaran yang bisa dijalankan oleh perusahaan pun tidak harus terpaku pada lingkup 4P (untuk perusahaan manufaktur) atau 7P (untuk perusahaan jasa) saja, tetapi bisa lebilbanyak lagi(G oi, 2009)

\section{Proses Pemasaran}

Dalam menghadapi fungsi pemasaran yang komplek seperti yang telah disebutkan di atas, diperlukan program dan kegiatan yang komprehensif agar tujuan perusahaan dapat tercapai. Kotler dan Keller (2009) merumuskan proses pemasaran tersebut sebagai proses dalam analisis, perencanaan, penerapan dan pengendalian program bauran pemasaran, yang dirancang untuk menciptakan, mempertahankan dan mengembangkan pertukaran yang saling menguntungkan pelanggan, organisasi dan stakeholder yang lain. Hal itu berarti proses pemasaran mempunyai fokus pada pelanggan, yang dimulai dari kegiatan untuk mengidentifikasi kebutuhan dan keinginan pelanggan, baik yang didasarkan pada prediksi dari hasil riset kepada pelanggan, pesaing dan lingkungan eksternal dan internal perusahaan maupun dari perspektif manajemen.

Hasil identifikasi pelanggan bila dilakukan dengan segmentasi pasar akan menghasilkan keputusan tentang pasar sasaran yang harus dilayani dan akan berdampak pada optimalisasi bisnis perusahaan. Tindak lanjut pilihan pasar sasaran memerlukan adanya program dan kegiatan yang terintegrasi dari bauran pemasaran yang ada (lihat misalnya Goi, 2009), berikut keputusan untuk memberikan prioritas program tertentu sesuai dengan tahapan hidup produk, tingkat pemahaman dan keterlibatan pelanggan pada aktivitas pema- 
saran yang akan dan telah dilakukan, tingkat persaingan, perkembangan teknologi dan faktor eksternal dan internal pemasaran yang lain.

Selanjutnya proses pemasaran akan terus berlanjut berupa kegiatan lain yang dapat meningkatkan kemungkinan kontinuitas hidup perusahaan melalui hubungan jangka panjang antara pelanggan, perusahaan dan stakeholder yang lain. Karena itu kegiatan pemasaran yang mengarah pada tanggungjawab sosial kepada semua stakeholder tersebut menjadi suatu keniscayaan untuk dilakukan perusahaan (Marketing Staff, 1965).

\section{Agenda Penelitian Pemasaran}

Untuk menjadi suatu ilmu, suatu disiplin harus memenuhi beberapa syarat, di antaranya adalah dapat dilakukan klasifikasi dan sistematika pengetahuan, mengacu pada satu atau beberapa teori sentral, dan bisa digunakan untuk prediksi dan pengendalian peristiwa di masa depan (Brown, 1997). Syarat-syarat tersebut dapat dipenuhi, di antaranya melalui pengalaman penelitian, karena pengembangan suatu disiplin ilmu tidak terlepas dari praktek penelitian yang dilakukan oleh kelompok orang dari disiplin tersebut.

Pada setiap kegiatan penelitian, seorang peneliti perlu mengemukakan secara jelas tentang pentingnya penelitian itu dilakukan dengan tema atau topik tertentu. Penjelasan itu memuat rincian alasan atau latar belakang yang komprehensif dan sesuai dengan konteks dan kondisi obyektif, seperti yang tersirat ditunjukkan dalam tema atau topik penelitian tersebut.

Konteks penelitian berhubungan dengan penekanan penelitian pada aspek tertentu yang dianggap penting untuk diteliti, sedangkan kondisi bersangkutan dengan fenomena yang terjadi dan berkaitan dengan realitas obyek yang diteliti [perusahaan, produk, merek]. Jika kontekstual merujuk pada teori yang dipakai dan mendasari tema pokok penelitian, maka kondisi dapat dicerminkan oleh variabel, atribut, atau sifat dari obyek itu. Untuk sampai pada tingkatan kondisional, maka variabel, atribut, atau sifat obyek harus sesuai dengan muatan teori yang dipilih dalam penelitian.

Demikian eratnya hubungan antara kontekstual dan kondisional penelitian ini, sehingga tidak boleh terjadi dalam suatu penelitian terdapat alasan atau latar belakang penelitian yang tidak menyentuh penjelasan tentang teori dan obyek penelitian. Dengan kata lain, peneliti perlu menjelaskan teori yang digunakan dalam penelitian -di antara berbagai teori yang mungkin ada - dan obyek yang dipilih sudah harus tertentu.

Di samping itu penting pula dikemukakan tujuan dilakukannya suatu penelitian. Tujuan penelitian bisa bermacammacam. Penelitian sebagai salah satu kegiatan ilmiah bisa dimaksudkan untuk mengembangkan ilmu, membuktikan teori, memenuhi rasa ingin tahu, atau mengumpulkan informasi yang dapat digunakan sebagai dasar manajemen untuk menetapkan keputusan bisnis. Pada tiga tujuan penelitian pertama tersebut masih jarang dijumpai konteks penelitian yang berkaitan dengan kepentingan khusus perusahaan, misalnya penelitian yang berhubungan dengan konsep atau paradigma pemasaran yang dipegang oleh perusahaan tertentu. Padahal konsep dan paradigma tersebut -seperti yang telah dibahas di depan - menjadi nilai atau pedoman dasar perusahaan untuk pengambilan keputusan dan kegiatan manajemen sehari-hari. Hal ini bisa disebabkan karena peneliti secara pribadi mempunyai tujuan tujuan penelitian sendiri yang searah dengan prosedur dan konteks penelitian yang ditujukan untuk mengembangkan ilmu, membuktikan teori, atau sekedarmemenuhi rasa ingin tahu peneliti.

Sementara itu untuk memenuhi tujuan penelitian terakhir pelaksanaan penelitian dapat dilakukan oleh tenaga peneliti internal atau eksternal perusahaan. Tenaga peneliti internal akan melibatkan anggota peneliti yang berasal dari dalam perusahaan sendiri, sedangkan peneliti eksternal berasal dari individu, lembaga, atau pihak lain di luar perusahaan, baik dilakukan dengan atau tanpa sponsor dari perusahaan.

Tujuan penelitian yang manapun sesungguhnya dapat dikaitkan dengan kondisi perusahaan yang diteliti. Jika hal ini dilakukan, maka hasil penelitian akan lebih kontekstual, aplikatif dan obyektif. Sebagai ilustrasi adalah jika peneliti akan melakukan penelitian dengan melibatkan subyek satu atau beberapa perusahaan, maka dia terlebih dahulu perlu melakukan survei ringan yang berkaitan dengan konsep bisnis atau paradigma pemasaran yang 
dipegang oleh perusahaan agar hasil penelitiannya dapat memberi manfaat kepada perusahaan yang diteliti tersebut.

Seperti halnya yang telah dibahas pada bagian konsep bisnis dan paradigma pemasaran, kecenderungan hubungan keduanya dapat dikelompokkan menjadi: (1) konsep produksi, produk dan penjualan cenderung menerapkan paradigma terjadinya pertukaran dari Kotler and Keller (2009), (2) konsep pemasaran dan pemasaran berwawasan sosial cenderung diterapkan dengan paradigma pencapaian kepuasan dan kebahagiaan konsumen atau manajemen layanan dari Stauss (2005), dan (3) konsep keseimbangan identitas merek dan fokus pada pelanggan lebih cocok dilakt kan dengan paradigma hubungan jangka panjang dengan pelanggan dari Gronroos (1994) dan Hunt (1991; 1994).

Konteks penelitian dari pengelompokan hubungan konsep-paradigma di atas bisa berpengaruh terhadap hubungan antar variabel yang dikembangkan dari kerangka atau model penelitiannya. Menurut Morgan (1996) sebuah model teoritis adalah: (1) unit yang merupakan hasil interaksi subyek penelitian; model kemudian menentukan cara unit-unit tersebut berinteraksi satu sama lain menjadi (2) hukumhukum interaksi; karena model teoritis umumnya dari bagian fenomena yang terbatas, (3) batas harus ditetapkan dalam waktu teori diharapkan dapat terus berlanjut; karena kebanyakan model teoritis dianggap mewakili sebagian kompleksitas dunia nyata, atau bagian dari kompleksitas yang terungkap oleh fakta bahwa ada berbagai (4) sistem yang masingmasing berinteraksi satu sama lain, yang menghasilkan (5) proposisi model, yang setelah diuji menjadi (6) indikator empiris, yang kemudian diubah menjadi pernyataan proporsional hipotesis, yang (7) diuji melalui penelitian.

Konsekuensi dari model hubungan konsep-paradigma dalam pemasaran adalah, misalnya pengelompokan yang pertama bisa hanya sampai pada model yang berujung pada variabel keputusan pembelian, banyaknya pembelian atau optimalisasi laba. Sedangkan pada pengelompokan kedua variabel akhir tersebut mungkin tidak cukup, tetapi perlu diperdalam lagi dengan kemungkinan terjadinya loyalitas pelanggan dalam pembelian ulang, membayar dengan harga lebih mahal, atau bahkan kesediaan untuk memberi saran dan rekomendasi positif kepada orang lain (word of mouth WOM). Sementara itu pada pengelompokan hubungan konsep-paradigma yang ketiga bisa lebih jauh lagi, yaitu perlunya pengungkapan tingkat loyalitas pelanggan sampai kemungkinan pelanggan untuk bersedia terlibat pada acara yang didesain oleh perusahaan, membangun kepentingan perusahaan, atau bahkan menjadi anggota kelompok fanatik produk dan kebijakan perusahaan.

Dengan pendekatan model yang berkembang dalam dunia penelitian tersebut di atas, maka penelitian pemasaran lebih banyak mengarah dengan metode kuantitatif dan pendekatan positivisme dan empirisme. Banyak jurnal ilmiah di dunia, yang seharusnya bisa menjadi media utama dalam distribusi dan cara mengembangkan gagasan teori para peneliti dan akademisi, juga membatasi pemuatan hasil penelitian kualitatif ini (Hunt, 1994; Peter and Olson, 1983). Akibatnya adalah rendahnya motivasi melakukan penelitian dan sedikitnya jumlah penelitian dengan pendekatan metode kualitatif dan dengan pendekatan relativisme, konstruksionisme, dan subyektivisme.

Kondisi tersebut tersebut karena berkembang suasana yang dikenal dengan "argumen standar untuk metode kualitatif" (Hunt, 1994), yaitu bahwa: (1) semua disiplin harus memiliki paradigma, (2) ada satu paradigma yang dominan dalam penelitian pemasaran, (3) pardigma yang dominan dalam pemasaran adalah positivisme, (4) filsafat ilmu telah meninggalkan positivisme dan, karena itu, paradigma dominan pemasaran telah didiskreditkan, (5) setelah meninggalkan positivisme, filsafat ilmu memeluk relativisme, konstruksionisme, dan subyektivisme, oleh karena itu (6) pemasaran harus menerima metode kualitatif. Padahal untuk sampai penggunaan metode kualitatif tidak diperlukan prosedur argumen tersebut, karena menurut Hunt (1994) empat premis di atas (1, 2, 3 dan 5) adalah palsu, dan premis (4) adalah menyesatkan. Dengan kata lain, seharusnya penggunaan metode penelitian kuantitatif dan kualitatif didasarkan pada konteks penelitiannya, agar pemasaran sebagai suatu ilmu dapat berkembang lebih baik.

$$
\text { Lebih jauh Desphande (1983) }
$$
memberikan pedoman penggunaan pendekatan penelitian berdasarkan pada paradigma kualitatif dan kuantitatif seperti yang tercantum dalam Tabel 1. 
Tabel 1: Karakteristik Paradigma Penelitian Kualitatif dan Kuantitatif

\begin{tabular}{|c|c|}
\hline Paradigma Kualitatif & Paradigma Kuantitatif \\
\hline Metoda kualitatif & Metoda kuantitatif \\
\hline $\begin{array}{l}\text { Memahami perilaku manusia dari sudut pandang si } \\
\text { aktor (emic) }\end{array}$ & $\begin{array}{l}\text { Mencari fakta atau penyebab fenomena sosial secara } \\
\text { obyektif (etic) }\end{array}$ \\
\hline Pendekatan fenomenologi & Pendekatan logical-positivism \\
\hline $\begin{array}{l}\text { Uncontrolled, naturalistic observational } \\
\text { measurement }\end{array}$ & Obtrusive, controlled measurement \\
\hline $\begin{array}{l}\text { Subyektif, insider perspective, tidak menjaga jarak } \\
\text { dengan data }\end{array}$ & $\begin{array}{l}\text { Obyektif, outsider perspective, menjaga jarak } \\
\text { dengan data }\end{array}$ \\
\hline $\begin{array}{l}\text { Grounded, discovery oriented, exploratory, } \\
\text { expansionist, descriptive, inductive }\end{array}$ & $\begin{array}{l}\text { Ungrounded, verification oriented, confirmatory, } \\
\text { reductionist, inferential, hypothetico-deductive }\end{array}$ \\
\hline Orientasi proses & Orientasi hasil \\
\hline $\begin{array}{l}\text { Validitas sangat penting, nyata, kaya, dan } \\
\text { mendalam }\end{array}$ & $\begin{array}{l}\text { Reliabilitas sangat penting, hard data, data mudah } \\
\text { direplikasi }\end{array}$ \\
\hline Holistik, sintesa & Partikularistik, analisis \\
\hline
\end{tabular}

Jika dilihat dari karakteristik masingmasing paradigma pada Tabel 1 tersebut, maka kualitatif lebih mengarah pada kekuatan subyektifitas perasaan peneliti dari pada logika mereka. Sehingga hasil penelitiannya pun lebih mungkin akan diperoleh hasil yang lebih variatif sesuai dengan kemampuan perasaan yang dipunyai peneliti untuk mengolah informasi yang diperolehnya. Meskipun demikian secara aplikatif kedua pendekatan paradigma tersebut bisa menunjang satu sama lain untuk menguatkan hasil penelitian yang diperoleh.

Selain berdasarkan pada pendekatan paradigma tersebut di atas, menurut Peter and Olson (1983) titik pandang ilmu juga dapat dicirikan dengan adanya perbedaan pendekatan terminologi filosofi, yang kemudian akan menimbulkan berbagai teknik pemecahan masalah dengan pendekatan positivistikempiris (PE) atau relativistik-konstruksionis (K ). Perbedaan kedua pendekatan tersebut dapat ditunjukkan lebih rinci pada Tabel 2.

Selanjutnya Peter and Olson (1983) menyatakan bahwa untuk pengembangan pemasaran penggunaan pendekatan RK lebih baik dibandingkan dengan PE, karena pendekatan RK mampu menghasilkan teoriteori yang lebih kreatif dan bermanfaat. Penggunaan RK tersebut cenderung sebagai bentuk aktivitas seni bagi manajemen. Walaupun demikian penggunaan kedua pendekatan tersebut perlu disesuaikan dengan jenis penelitiannya yang dilakukan. Artinya jika memungkinkan cukup digunakan pendekatan PE maka tidak ada hambatan yang akan diperoleh, atau sebaliknya. Yang diperlukan dalam tataran aplikasi tersebut adalah pelaksanaan prosedur dan prinsip-prinsip yang dipersyaratkan untuk mencapai hasil penelitian yang baik dan terpercaya.

Pada dua dekade terakhir juga muncul era pendekatan penelitian yang disebut pendekatan postmodernisme. Meskipun pada awalnya dianggap sebagai salah satu di antara banyak mode intelektual, postmodernisme sekarang menempati posisi penting dalam segala macam disiplin ilmu. Mengingat hegemoni wacana postmodern dalam lingkungan intelektual dan peran penting yang dimainkan oleh artefak pemasaran dan praktek, tidak mengherankan bahwa konsep ini telah menarik perhatian. Postmodernisme menawarkan sejumlah atraksi signifikan bagi pemasar dan memberikan dasar. Ia memberikan prospek perbaikan pemasaran hubungan antara teori dan praktek. Dengan penekanan pada ekumenisme akademik dan pluralitas epistemologis, postmodernisme memberikan alasan untuk fragmentasi pemikiran pemasaran terkini. Selain itu, postmodernisme memberikan banyak restorasi yang banyak disinggung pemasaran saat ini, seperti mikro-marketing dan pemasaran database. 
Tabel 2: Perbedaan Rincian Pendekatan PE dan RK

\begin{tabular}{|c|c|}
\hline Positivistik / empiris Sains & Relativistik / konstruksionis Ilmu \\
\hline Sains menemukan sifat sejati dari realitas & Sains menciptakan banyak realitas \\
\hline $\begin{array}{l}\text { Hanya logika pembenaran yang diperlukan untuk } \\
\text { memahami ilmu pengetahuan }\end{array}$ & $\begin{array}{l}\text { Proses teori yang dibuat, dibenarkan, dan menyebar } \\
\text { sepanjang sebuah komunitas riset diperlukan } \\
\text { untuk memahami ilmu pengetahuan }\end{array}$ \\
\hline $\begin{array}{l}\text { Ilmu dapat dipahami tanpa mempertim-bangkan } \\
\text { faktor budaya, sosial, politik, dan ekonomi }\end{array}$ & $\begin{array}{l}\text { Sains adalah proses sosial dan tidak dapat dipahami } \\
\text { tanpa mempertimbangkan faktor budaya, sosial, } \\
\text { politik, dan ekonomi }\end{array}$ \\
\hline Ilmu bersifat obyektif & Ilmu adalah subyektif \\
\hline Pengetahuan ilmiah adalah mutlak dan kumulatif & $\begin{array}{l}\text { Pengetahuan ilmiah adalah relatif terhadap konteks } \\
\text { dan periode waktu tertentu }\end{array}$ \\
\hline $\begin{array}{l}\text { Ilmu mampu menemukan hukum-hukum universal } \\
\text { yang mengatur dunia }\end{array}$ & $\begin{array}{l}\text { Sains menciptakan ide-ide yang tergantung pada } \\
\text { konteks, yaitu relatif terhadap suatu kerangka } \\
\text { acuan }\end{array}$ \\
\hline $\begin{array}{l}\text { Ilmu menghasilkan teori-teori yang mendekati } \\
\text { kebenaran mutlak }\end{array}$ & $\begin{array}{l}\text { Kebenaran adalah evaluasi subjektif yang tidak } \\
\text { dapat disimpulkan dengan baik di luar konteks } \\
\text { yang diberikan oleh teori tersebut }\end{array}$ \\
\hline $\begin{array}{l}\text { Sains adalah rasional karena mengikuti aturan-aturan } \\
\text { logika formal }\end{array}$ & $\begin{array}{l}\text { Tingkat rasionalitas ilmu bertujuan untuk } \\
\text { meningkatkan kesejahteraan individu dan sosial } \\
\text { dengan mengikuti segala cara yang berguna } \\
\text { untuk melakukannya }\end{array}$ \\
\hline $\begin{array}{l}\text { Ada aturan khusus untuk menentukan ilmu adalah } \\
\text { sah (dari pemalsuad) }\end{array}$ & $\begin{array}{l}\text { Ada banyak cara menentukan ilmu sah, sesuai } \\
\text { dengan perbedaan situasi }\end{array}$ \\
\hline $\begin{array}{l}\text { Untuk menghindari potensi pemalsuan, teori perlu } \\
\text { melalui pengujian empiris yang ketat dari } \\
\text { ilmuwan }\end{array}$ & $\begin{array}{l}\text { Para ilmuwan mencari dukungan dan bukti } \\
\text { konfirmasi untuk memasarkan teori mereka }\end{array}$ \\
\hline $\begin{array}{l}\text { Prosedur pengukuran tidak mempengaruhi apa yang } \\
\text { diukur }\end{array}$ & $\begin{array}{l}\text { Tidak ada yang bisa diukur tanpa mengubah } \\
\text { ukurannya }\end{array}$ \\
\hline $\begin{array}{l}\text { Menyediakan data objektif dan benchmark } \\
\text { independen untuk pengujian teori }\end{array}$ & $\begin{array}{l}\text { Data diciptakan dan diinterpretasikan oleh dan } \\
\text { dengan berbagai teori }\end{array}$ \\
\hline
\end{tabular}

Postmodern merupakan suatu upaya untuk berpikir historis pada saat sekarang karena telah melupakan cara untuk berpikir secara historis pada masa lalu (Brown, 1997). Secara umum postmodernisme ditandai dengan kondisi skeptis, subversif, ironi, anarki, main main, paradoks, gaya, self-referentiality dan sikap permusuhan terhadap generalisasi. Postmodernis menolak upaya untuk memaksakan ketertiban dan koherensi atas kekacauan dan fragmentasi realitas. Sebaliknya, kita harus menerima pengetahuan bahwa kemampuan kita untuk membentuk generalisasi bermakna terbatas dan, daripada mencari ketidakmungkinan kebenaran universal, kita harus menerima kontingensi, ephemeralitas dan keragaman fisik dan manusia sebagai kita mengalami mereka, merasa nyaman dalam tidak adanya kepastian, belajar untuk hidup tanpa penjelasan definitif dan mengakui bahwa tujuan pencerahan yang utopis dan tak terjangkau (Brown, 1993).

Menurut Brown (1993), postmodern menawarkan sejumlah sejumlah atraksi signifi- kan bagi pemasar dan memberikan dasar konseptual pada perdebatan disiplin pemasaran, di antaranya adalah (1) memperbaiki hubungan antara teori dan praktek berkaitan dengan birokrasi dan realitas pemasaran, misalnya pada perilaku konsumsi pasca pembelian; (2) memberi alasan fregmentasi pemikiran pemasaran dengan penekanan pada akademik dan pluralisme epistemologis, humanisme, eksistensialisme, atau fenomenologi.

(3) memberi banyak restorasi pada mikro-marketing, maxi-marketing, hubungan pemasaran, atau pemasaran database, atas penekanan variasi keunikan, pluralitas dan keanehan yang berkaitan dengan pelanggan sebagai individu dan keinginan untuk mempertahankan pelanggan yang sudah ada; dan (4) menawarkan pencarian di bidang akademik pemasaran, terutama untuk membuktikan bahwa pemasaran lebih ilmiah daripada ilmu pengetahuan, tidak hanya menyediakan dasar konseptual akhir individualistik, idiographik dan intuitif dari ilmu pengetahuan seni, tetapi 
juga keikutsertaan pada hirarki struktur organisasihorizontal dan vertikal.

Di bidang pemasaran postmodernisme berperan mempercepat pemikiran-pemikiran baru pada konsep dan teori pemasaran yang sudah dianggap mapan, karena konsep dan teori tersebut masih ditemukan kelemahan.

\section{PENUTUP}

Perbedaan pendapat dalam usaha pengembangan konsep bisnis dan operasionalisasi kegiatan pemasaran adalah suatu keniscayaan. Namun perbedaan tersebut seharusnya dikemas menjadi kritik konstruktif dan dapat menjadi pilihan dalam rangka membantu arah perkembangan disiplin pemasaran yang lebih cepat dan kaya variasi dalam pemecahan masalah manajemen yang mungkin terjadi.

Dalam disiplin ilmu pemasaran banyak dijumpai perbedaan pendapat berkaitan dengan konsep bisnis, paradigma, bidang kerja, fungsi, proses, dan bahkan perlunya pemasaran dikembangkan dengan pendekatan penelitian tertentu. Agar kegiatan keilmuan dan aplikasi pemasaran dapat berjalan selaras, maka diskusi diarahkan pada perlunya sinkronisasi antara pilihan konsep bisnis yang diusulkan dan digunakan sebagai pedoman diskusi dengan program dan operasionalisasi kegiatan sampai pada pendekatan pengendaliannya, termasuk pilihan pendekatan dalam melakukan agenda penelitian pemasaran. Jika sampai saat ini pendekatan penelitian kuantitatif lebih mendominasi, maka ke depan perlu diimbangi juga dengan dilakt kannya penelitian kualitatif, terutama untuk mengeksplorasi kemungkinan redesain dari konsep bisnis dan faktor-faktor lanjutannya. Bahkan jika diperlukan penggunaan pendekatan postmoderinsme dalam penelitian adalah suatu keniscayaan.

\section{DAFTAR PUSTAKA}

Ames, BC. 1970. Trappings vs Substance in Industrial Marketing. Harvard Business Review. July-August. 93-102.

Bagozzi, R. 1975. Marketing as Exchange. Journal of Marketing. 39 (4). 32-39.

Bagozzi, RP. and R. Nataraajan 2000. The Year 2000: Looking Forward. Psychology and Marketing. 17 (1). 1-6.
Bartels, R. 1988. The History of Marketing Thought. $3^{\text {th }}$ Eds. Ohio: Publishing Horizon Inc.

Brown, S. 1993. Postmodern Marketing. European Journal of Marketing. 27 (4). 19-35.

Brown, S. 1997. Marketing Science in a Postmodern Worl: Introduction to the Special Issuee. European Journal of Marketing. 31 (3,4). 167-176.

Brown, S. 2002. Vote, Vote, Vote for Philip Kotler. European Journal of Marketing. 36 (3). 313-326.

Deshpande, R. 1983. Paradigma Lost: on Theory and method in Research in Marketing. Journal of Marketing. 47. 101-110.

Goi, CL. 2009. A Review of Marketing Mix: 4Ps or More?. International Journal of Marketing Studies. 1 (1). 1-15.

Graham, P. 1993. Marketing's Domain: A Critical Review of the Development of the Marketing Concept. Marketing Bulletin. 4 (1). 1 -11.

Grant, C. 1999. Theodore Levitt's Marketing Myopia. Journal of Business Ethics. 18 (4). 397-407.

Gronroos, C. 1994. From Marketing Mix to Relationship Marketing: Towards a Paradigma Shift in Marketing. Management Decision. 32 (2). 4-18.

Houston, FS. 1986. The Marketing Concept: What It Is and What It Is Not. Journal bf Marketing. 50 (2). 81-89.

Hunt, SD. 1976. The Nature and Scope of Marketing. Journal of Marketing. 40 (3). 17-28.

Hunt, SD. 1991. Modern Marketing Theory: Critical Issues in the Philosophy of Marketing Science. Ohio: SouthWestern Publishing Co.

Hunt, SD. 1994. On Rethinking Marketing: Our Disipline, Our Practice, Our Methods. European Journal of Marketing. 28 (3). 13-26. 
Keith, RJ. 1960. The Marketing Revolution. Journal of Marketing. 24 (January). 3538.

Kotler, P. and KL. Keller 2009. Marketing Management. $13^{\text {th }}$ Eds. New Jersey: Pearson Prentice Hall.

Kotler, P. 1972. A Generic concept of Marketing. Journal of Marketing. 36 (April). 46-54.

Kotler, P. 1984. Marketing Management: Analysis, Planning and Control. $5^{\text {th }}$ Eds. New Jersey: Prentice Hall, Inc.

Kotler, P. and SJ. Levy 1969. Broadening the Concept of Marketing. Journal of Marketing. January. 10-15.

Laczniak, GR., RF. Lusch and JG. Udell 1977. Marketing in 1985: A View from the Ivory Tower. Journal of Marketing. 41 (4, Oct). 47-56

Levitt, T. 1960. Marketing Myopia. Harvard Business Review. Jul-Aug. 45-63.

Marketing Staff of the Ohio State University 1965. A Statement of Marketing Philosophy. Journal of Marketing. 29 (1, Jan). 43-44.
Mintzberg, H. 2005. Developing Theory about the Development of Theory. In KG. Smith and MA. Hitt (Editors). Great Minds in Management: the Process of Theory Development (p. 355-372). New York: Oxford University Press Inc.

Morgan, RE. 1996. Conceptual Foundations of Marketing and Marketing Theory. Management Decision. 34 (10). 19-26

Peter, JP. and JC. Olson. 1983. Is Science Marketing?. Journal of Marketing. 47. 111-125.

Shaw, EH. and RD. Tamilia 2001. Robert Bartels and the History of Marketing Thought. Journal of Macromarketing. 21 (2, December). 156-163.

Sheth, JN., DM. Gardner and DE. Gerret 1988. Marketing Theory: Evolution and Evaluation. Canada: John Wiley \& Sons, Inc.

Stauss, B. 2005. A Pyrrhic Victory: The Implications of an Unlimited Broadening of the Concept of Services. Managing Service Quality. 15 (3). 219 230. 